\title{
Sexual dimorphism in winter survival rate differs little between damselbug species (Heteroptera: Nabidae)
}

\author{
STEFFEN ROTH ${ }^{1}$ and KLAUS REINHARDT ${ }^{2}$ \\ ${ }^{1}$ Department of Biology, Ecological and Environmental Change Research Group, University of Bergen, Postbox 7800, \\ N-5020 Bergen, Norway; e-mail: steffen.roth@macnews.de \\ ${ }^{2}$ University of Sheffield, Department of Animal and Plant Sciences, Sheffield S10 2TN, UK; e-mail: k.Reinhardt@sheffield.ac.uk
}

Key words. Winter survival, overwintering, low temperature experiment, sexual dimorphism, Nabidae, Heteroptera, Nabis rugosus, N. ericetorum. N. pseudoferus

\begin{abstract}
The winter survival of three closely related univoltine heteropterans that overwinter as adults, Nabis rugosus, N. ericetorum and $N$. pseudoferus was investigated. After 150 days of low temperature treatment $\left(3-5^{\circ} \mathrm{C}, 16 \mathrm{~L}: 8 \mathrm{D}\right.$, r.h. $\left.70-80 \%\right)$ more males than females died. The mortality rate ranged from 88.8 to $93.8 \%$ in males and from 54.2 to $60.7 \%$ in females. However, these sexual differences in mortality did not differ significantly across the three species and populations of different geographic origin. It remains a general question whether this considerable evolutionary stability in the sex-specific investment into reproduction and survival phylogenetically conserved or frequently evolves anew to similar levels in separated populations and species. In Nabis rugosus, the relative loss of body mass during overwintering was up to $37.8 \%$. This reflects dramatic somatic costs of adult overwintering and indirectly supports the hypothesis that food supply during overwintering is important for some heteropteran predators. However, body mass before overwintering did not significantly explain the survival pattern in N. rugosus in either sex. The similar sex-specific survival rate of overwintering adult nabids regardless of species and geographic origin can be useful for studies on population dynamics of nabids in agroecosystems and biocontrol.
\end{abstract}

\section{INTRODUCTION}

Dormancy, a typical feature in the life cycle of many animals in temperate zones (Danks, 1987) allows organisms to synchronize their reproductive or developmental cycle with predictably changing environmental conditions by suppression of growth, development and reproduction, the depression of metabolism and the enhancement of stress resistance to promote survivorship (Danks, 1987). There is an extensive literature on insect seasonality, the diversity and complexity of dormancy in insects (reviewed in Tauber et al., 1986; Danks, 1987, 2007) from which two important issues emerge: sexual dimorphisms and geographic variation. In this paper we examine the winter survival of both sexes in three species of damselbugs from different geographic origins.

Pener (1992) suggested that enhanced survival during unfavourable conditions should benefit males and females equally and one should not expect sex differences in dormancy. However, given that the way males and females maximise fitness is fundamentally different, gender differences in resource allocation to current and future reproductive investment, and therefore, winter survival may well be expected. For example, in some insect species only females survive to the following spring, storing viable sperm for reproduction (Danks, 1987; Pener, 1992). Indeed, there are sexual differences in the intensity of dormancy (Selander \& Weedle, 1972; Sims \& Shapiro, 1983), photoperiodic, temperature and food requirements (Meinke \& Slosser, 1985; Tachibana \& Watanabe, 2007) development during reproductive dormancy (Tatar et al., 2001) and duration of dormancy (e.g. protandry) (Nylin
\& Gotthardt, 1998). In general, sex differences in dormancy are well documented but poorly understood as many studies on the regulation of diapause include only females and neglect males (Tauber et al., 1986; Danks, 1987).

Heteroptera that overwinter as adults generally have a high mortality during hibernation (up to 40 to $65 \%$ Musolin \& Saulich, 1999) and the Nabidae do not seem to be an exception (Kott et al., 2000; Roth \& Remane, 2003). If mortality rates are so high, they may be particularly useful in revealing sexual differences.

Geographic variation in induction and duration of dormancy in insects (Denno \& Dingle, 1981; Taylor \& Karban, 1984; Danks, 1987) has long been known. If duration of dormancy and proportion of dormant insects vary geographically it is likely that (a) hibernation mortality and (b) sexual differences in hibernation mortality also vary geographically. This could select for different reproductive and life-history strategies across a species' range. To test this in Nabidae, mortality when kept at low temperatures was recorded for Nabis rugosus from two geographic regions, The Netherlands and central Germany, with different winter conditions.

Nabids are economically important predators in biological control (Lattin, 1989; Braman, 2000). Even though factors inducing and terminating dormancy were not the aim of this study, the experiment elicited some general information on winter survival for this poorly studied group of insects (Ruberson et al., 1998; Roth \& Remane, 2003). In particular, facultative feeding of overwintering predatory heteropteran adults in proposed as a 
crucial factor determining mortality (Ruberson et al., 1998) and so we assessed the somatic costs for one of the species, Nabis rugosus.

\section{MATERIAL AND METHODS}

\section{The study species and collection}

The three study species, Nabis pseudoferus Remane 1949, N. ericetorum Scholtz 1847 and N. rugosus (Linnaeus, 1758) have similar life histories. All are univoltine in Central Europe and overwinter as adults (Remane, 1964; Kerzhner, 1981; Pericart, 1987). Whilst mating occurs before and after overwintering (i.e. in autumn and spring), development of ovaries and oviposition always occurs in spring (Roth \& Remane, 2003; Roth \& Reinhardt, 2003).

\section{Population origins}

Nabis pseudoferus was collected in several grassland habitats in Thuringia (eastern Germany) in late summer and autumn, and $N$. ericetorum in heathlands in the northeastern parts of The Netherlands (province Gelderland). Nabis rugosus was collected from two locations (i) grassland and woodland habitats in Thuringia and (ii) similar habitats in northern Netherlands (province Gelderland).

The Thuringian habitats are in the humid continental climate zone (Köppen-Geiger-category: Dfb; Peel et al., 2007). Monthly winter temperature averages for 1961-1990 ranged from -1.3 to $3.6^{\circ} \mathrm{C}$ (mean $1.0^{\circ} \mathrm{C}$ ) (www. klimadiagramme.de/deutschland $2 /$ html).

The Dutch habitats are situated in the Oceanic climate zone (Köppen-Geiger-category: Cfb; Peel et al., 2007), where mean winter temperatures range between 2.1 and $5.0^{\circ} \mathrm{C}$ (mean $3.8^{\circ} \mathrm{C}$ ) (www.klimadiagramme.de/Europa/niederlande.html). The distance between the German and Dutch sampling sites is about $550 \mathrm{~km}$.

\section{Rearing}

Individuals of Nabis ericetorum $(\mathrm{n}=67), N$. pseudoferus $(\mathrm{n}=$ $41)$, and $N$. rugosus $(\mathrm{n}=45)$ were collected using a sweepnet and taken live to the laboratory. There, all individuals were exposed to a light regime of $15 \mathrm{~L}: 9 \mathrm{D}$ (September) and 13L : $11 \mathrm{D}$ (October) and temperatures ranging from 12 to $18^{\circ} \mathrm{C}$. Because these conditions mimic ambient temperatures it is likely that any ongoing physiological changes occurring before winter dormancy were not affected. All bugs were kept individually in Petri dishes (diameter $10 \mathrm{~cm}$ ) lined with moist tissue paper as a source of water. Individuals were fed with about 10 Drosophila per day, i.e., an ad libitum food supply (Roth et al., 2008) until the beginning of the overwintering study.

\section{Winter mortality and physical conditions}

After six weeks in culture the insects were transferred to a low temperature treatment that mimics overwintering conditions. Individuals were kept at $3-5^{\circ} \mathrm{C}, 6 \mathrm{~L}: 18 \mathrm{D}$ and relative humidity of $70-80 \%$ for 150 days until March 12, 2001. Water but no food was provided in order to mimic low prey availability in winter but to prevent dehydration, which is one of the most significant factors in dormant insects (Danks, 2000) but possibly not very relevant in the mild and humid winter conditions experienced by the nabid populations studied. Every three days during the 150 day experiment the number of individuals surviving was recorded and the wet tissue paper replaced.

Somatic costs of survival were assessed in one species, Nabis rugosus, by analysing whether the survival rate was correlated with mass loss during overwintering. Body mass was measured one day before the beginning of the 150 day exposure period and (for surviving individuals) on the last day of the 150 days (analytical balance PCE-AB 100). The average body mass of the individuals at the start of the experiment (males $8.72 \mathrm{mg} \pm$ 1.02 , females $9.84 \mathrm{mg} \pm 0.35$ ) was within the range of field collected individuals of this species (6-12.5 $\mathrm{mg}$ for both sexes in Bulankova (1989). Fresh body mass before overwintering and total body length were not significantly correlated $(\mathrm{r}=0.115, \mathrm{~N}$ $=44, p=0.453$ ). This indicates that some individuals began the overwintering experiment with a greater weight to body length ratio than others. The effect of physical condition on survival was assessed using the decline in weight during the low temperature treatment.

\section{Data analysis and model selection}

Cox regression (Wittenberg \& Cramer, 1992) was used to simultaneously assess the effect of sex, species and species differences in sexual dimorphism (i.e., sex $\times$ species) on survival. Geographic origin was also considered as a factor and the interaction of geographic origin and sex was evaluated. This full model was reduced using a backward mode of variable exclusion based on significance testing by Wald's statistics. Simple models were preferred over complicated ones if the explanatory power was not significantly different based on F-tests (Crawley, 2002).

The relationship between initial body mass and survival was analysed in Nabis rugosus only. In a Cox regression we assessed the effect of geographic origin, mass and length before overwintering on survival by using sex as stratum. Because the data were used in the previous test, differences at $p<0.025$ were regarded as significant.

\section{RESULTS}

\section{Analysis of survival curves}

The sexes differed significantly in overwintering survival, but there was no effect of geographic origin or species (Tables 1, 2, Fig. 1).

\section{Effects of body condition on percentage survival in $N$. rugosus}

Decreases in the relative body mass of males and females ranged from $11.1-37.8 \%$ (average $25.6 \%, \pm \mathrm{SD}$ $7.53, \mathrm{n}=24)$. Whilst females started overwintering significantly heavier than males $(\mathrm{t}=2.55$, df $=43, \mathrm{p}=$

TABLE 1. Summary of the overwintering survival of males and females of three species of damselbugs (Nabidae). The two different populations of $N$. rugosus were combined. The mean survival times are averages of days survived within the 150 days of the experiment (survivors included with 150 days survival time), whereas the survival (in \%) refers to the percentage of living individuals at the end of the experiment, i.e. day $150 . \mathrm{n}$ denotes sample size.

\begin{tabular}{ccc}
\hline $\begin{array}{c}\text { Species and sex } \\
(\mathrm{n})\end{array}$ & $\begin{array}{c}\text { Mean survival time } \\
(\text { days } \pm \mathrm{SD})\end{array}$ & $\begin{array}{c}\text { Survival in \% } \\
(\mathrm{n})\end{array}$ \\
\hline $\begin{array}{c}\text { Nabis ericetorum } \\
\text { males (32) }\end{array}$ & $77.56( \pm 6.96)$ & $6.2(2)$ \\
females (35) & $112.46( \pm 8.01)$ & $40.0(14)$ \\
Nabis pseudoferus & & \\
males (18) & $73.35( \pm 10.70)$ & $11.1(2)$ \\
females (33) & $98.76( \pm 9.18)$ & $39.3(13)$ \\
Nabis rugosus & & \\
males (21) & $77.52( \pm 12.33)$ & $9.5(2)$ \\
females $(24)$ & $96.04( \pm 11.74)$ & $45.8(11)$ \\
\hline
\end{tabular}


TABLE 2. Cox regression of differences in survival during overwintering among individuals of Nabis rugosus (Nr), N. ericetorum $(\mathrm{Ne})$ and $N$. pseudoferus (Np), with species, sex and geographic origin as explanatory variables. For sample sizes see Table 1.

\begin{tabular}{lccccccc}
\hline & & B & SE & Wald & df & Sig. & Exp (B) \\
\hline Full model & Sex & 1.011 & 0.477 & 4.490 & 1 & 0.034 & 2.749 \\
& Species (all 3) & & & 0.879 & 2 & 0.644 & \\
& Species (Np vs. Ne) & -0.342 & 0.466 & 0.538 & 1 & 0.463 & 0.711 \\
& Species (Nr vs. Ne) & 0.243 & 0.416 & 0.342 & 1 & 0.559 & 1.275 \\
& Geographic origin & 0.334 & 0.540 & 0.382 & 1 & 0.536 & 1.397 \\
& Sex $\times$ species & & & 1.382 & 2 & 0.501 & \\
& Sex $\times$ species (1) & 0.649 & 0.615 & 1.115 & 1 & 0.291 & 1.914 \\
& Sex $\times$ species (2) & -0.301 & 0.583 & 0.266 & 1 & 0.606 & 0.740 \\
& Sex $\times$ geographic origin & -0.692 & 0.720 & 0.924 & 1 & 0.337 & 0.500 \\
\hline Final model & Sex & 0.800 & 0.189 & 18.007 & 1 & 0.000 & 2.226 \\
\hline
\end{tabular}

0.014), mass or length differences alone did not explain the differences in survival of the sexes (Table 3).

\section{DISCUSSION}

Species and population differences in the sexual dimorphism of life-history, traits including survival, have rarely been studied in insects (see e.g. Jennions et al., 2001; Fox et al., 2003; Maklakov et al., 2007). Some Drosophila studies show that sexual differences in senescence, stress resistance or thermal adaptations vary between populations (Sørensen et al., 2005; Norry et al., 2006) but in others the sexual dimorphism of life-history traits was consistent across populations or related species (Robinson et al., 2000; Hoffmann et al., 2001; Sharmila Bharathi et al., 2003). There is evidence that sex-specific trade-offs lead to sexual dimorphism of life-history traits, such as differences in cold resistance of males and females (Hoffmann et al., 2005). The question remains whether the mechanisms regulating the sex specific allocation into winter survival are phylogenetically conserved or frequently evolve anew to similar levels and thereby cause similar patterns across species and populations. While parsimony considerations would suggest interpreting the absence of sexual dimorphism differences between species as conserved, it has to be kept in mind that reproduc- tive traits are the fastest evolving traits and so could be relatively unconstrained evolutionarily.

In damselbugs (Nabidae), the factors inducing, maintaining and terminating seasonal dormancy are poorly understood (Koschel, 1971; Pericart, 1987; Ruberson et al., 1998). There is evidence that both diapause and quiescence might occur in European nabid species (Remane \& Thielen, 1973; Remane, 1964; Pericart, 1987; Roth \& Remane, 2003). Our data confirm that mortality rates of heteropterans, particularly predatory ones, that overwinter as adults can be very high (67-95\%) and so have substantial effects on population size (Horton et al., 1998; Ruberson et al., 1998; Musolin \& Saulich, 1999; Shimuzu $\&$ Kawasaki, 2001). Temperature, disease and predation are assumed to be the main mortality factors (Ruberson et al., 1998). Of the species studied, N. rugosus lost up to $37.8 \%$ of its body weight during hibernation, but for neither males nor females did higher body mass prior to the low temperature treatment enhance survival. The individual relative loss of body mass during overwintering showed a high and unexplained variability (ranging between 11.1 and $37.8 \%$ ).

Despite the different climate conditions experienced by the German and Dutch study sites, geographic origin did not affect sexual dimorphism survival measured in the same environment. Given that metabolic rates, dormancy

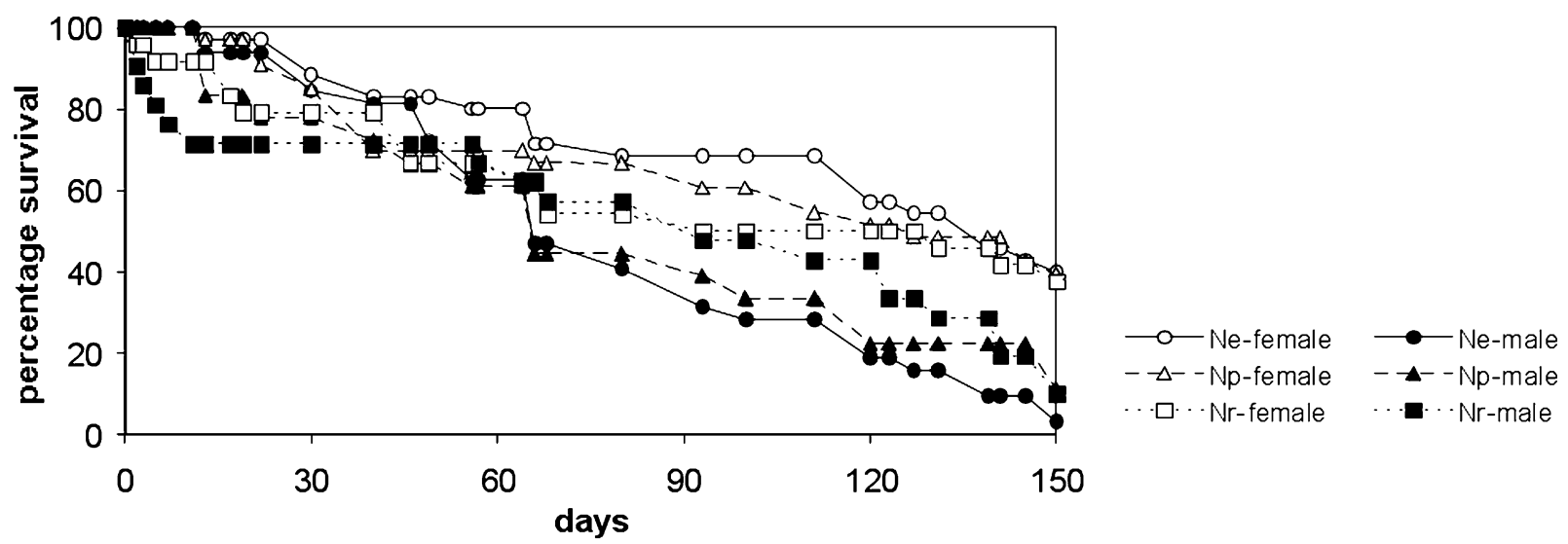

Fig. 1. Percentage survival of males and females of Nabis ericetorum $(\mathrm{Ne}), N$. pseudoferus $(\mathrm{Np})$ and N. rugosus $(\mathrm{Nr})$ during the 150 days of the overwintering experiment. 
TABLE 3. Cox regression of differences in survival among individuals of $N$. rugosus with geographic origin, mass and length before overwintering as variables, and sex as stratum.

\begin{tabular}{ccccccc}
\hline & B & SE & Wald & df & Sig. & Exp (B) \\
\hline Geographic origin & -0.192 & 0.378 & 0.257 & 1 & 0.612 & 0.825 \\
Mass & -0.246 & 0.157 & 2.467 & 1 & 0.116 & 0.782 \\
Length & 0.076 & 0.048 & 2.514 & 1 & 0.113 & 1.079 \\
\hline
\end{tabular}

induction, and cold-hardiness vary with geography and climate (e.g., Brown \& Hodek, 1983; Danks, 1987; Musolin \& Saulich, 1999; Ruberson et al., 2001; Shimizu \& Kawasaki, 2001), the absence of differences reported here are more surprising than would be their presence. Further information is needed to interpret the similar winter survival patterns of Nabids from different regions in general terms, as dormancy responses are so diverse because seasonal patterns vary regionally, locally and from year to year (Danks, 1987).

In this low temperature experiment a distinct sexual dimorphism in the percentage survival of the three species of damselbugs was found. These results are not exceptional: previous laboratory observations of a damselbug species, Prostemma guttula (Fabricius, 1787), also found higher female than male winter survival (Kott et al., 2000), and there is evidence from the field that nabid females survive hibernation better than males (Kott et al., 2000; Roth \& Remane, 2003). This is in accord with several studies that have demonstrated differential field survival of overwintering male and female heteropteran predators (e.g., Elkassabany et al., 1996; Ito \& Nakata, 1999).

As far as is known, all three species studied have a similar reproductive life cycle and mating system (Roth \& Remane, 2003). Therefore, species-specific differences in the mating systems are probably not implicated in the differences in survival patterns, as shown for other insects (Gotthard et al., 2000)

Whilst higher survival of females than males is reported for several insect taxa, including other Heteroptera (Musolin \& Saulich, 1999), its causes remain unclear. They could be based on sex differences in resource allocation to reproduction and survival. As argued earlier (Kott et al., 2000; Roth \& Reinhardt, 2003) males do not need to survive until females lay eggs in spring. It is sufficient that their sperm remains fertile while in the female. As such, males that copulate with females before or during diapause (e.g. Pener, 1992) may not be able to or may not need to survive. Depending also on the mating success of surviving males and their sperm's fertilisation success the next spring it remains to be tested whether such different allocation strategies are a strong enough selection pressure to lead to sexual differences in the proportion entering diapause. Whilst in our study most males and females appeared to be mobile, and so possibly were quiescent rather than dormant, we did not record the precise proportions. This is unfortunate because the proportion of individuals entering diapause may lead to differential overwintering mortality (Denlinger, 1981; Tachibana \& Watanbe, 2007). It remains, therefore, a valid possibility that sexual differences in overwinter sur- vival are caused by different proportions entering diapause or quiescence. If so, future research should be directed towards the question how such sex differences in survival and/ or entering diapause can be so similar across species.

ACKNOWLEDGEMENTS. We thank D. Musolin (Kyoto) for useful comments on a previous version of the manuscript, two anonymous referees, and C. Jenks (Bergen) for useful suggestions and remarks.

\section{REFERENCES}

Braman S.K. 2000: Damsel bugs (Nabidae). In Schaefer C.W. \& Panizzi A.R. (eds): Heteroptera of Economic Importance. CRC Press, Boca Raton, pp. 639-656.

Bulankova E. 1989: Linear relationship between live and dry weight in selected species of the family Nabidae (Hemiptera). Biologia (Bratislava) 44: 105-110.

Crawley M.J. 2002: Statistical Computing. An Introduction to Data Analysis Using S-Plus. John Wiley \& Sons, Hoboken NJ, 772 pp.

Brown V.K. \& Hodek I. (eds) 1983: Diapause and Life Cycle Strategies in Insects. Series Entomologica 23, W. Junk, The Hague, 300 pp.

Denno R.F. \& Dingle H. (eds) 1981: Insect Life History Patterns: Habitat and Geographic Variation. Springer, New York, $225 \mathrm{pp}$.

DANKS H.V. 1987: Insect Dormancy: An Ecological Perspective. Biological Survey of Canada, Ottawa, 439 pp.

DANKS H.V. 2000: Dehydration in dormant insects. J. Insect Physiol. 46: 837-852.

Danks H.V. 2007: The elements of seasonal adaptations in insects. Can. Entomol. 139: 1-44.

Denlinger D.L. 1981: Basis for a skewed sex ratio in diapausedestined flesh flies. Evolution 35: 1247-1248.

Elkassabany N., Ruberson J.R. \& Kring T.J. 1996: Seasonal distribution and overwintering of Orius insidiosus (Say) in Arkansas. J. Entomol. Sci. 31: 76-88.

Fox C.W., Dublin L. \& Pollitt S.J. 2003: Gender differences in mortality rates in two seed beetle species. Funct. Ecol. 17: 619-626.

Gotthart K., Nylin S. \& WikLund C. 2000: Mating opportunity and the evolution of sex-specific mortality rates in a butterfly. Oecologia 12: 36-43.

Hoffmann A.A., Hallas R., Sinclair C. \& Mitrovski P. 2001: Levels of variation in stress resistance in Drosophila among strains, local populations, and geographic regions: patterns for desiccation, starvation, cold resistance, and associated traits. Evolution 55: 1621-1630.

Hoffmann A.A., Hallas R., Anderson A.R. \& Telonis-Scott M. 2005: Evidence for a robust sex-specific trade-off between cold resistance and starvation resistance in Drosophila melanogaster. J. Evol. Biol. 18: 804-610.

Horton D.R., Lewis T.M., Hinojosa T. \&. Broers D.A. 1998: Photoperiod and reproductive diapause in the predatory bugs Anthocoris tomentosus, A. antevolens, and Deraecoris brevis 
(Heteroptera: Anthocoridae, Miridae) with information on overwintering sex ratios. Ann. Entomol. Soc. Am. 91: 81-86.

Iто K. \& NAKATA T. 1999: Diapause and survival in winter in two species of predatory bugs, Orius sauteri and O. minutus. Entomol. Exp. Appl. 89: 271-276.

Jennions M.D., Møller A.P. \& Petrie M. 2001: Sexually selected traits and adult survival: A meta-analysis. Q. Rev. Biol. 76: 3-36.

KERZHNER I.M. 1981: Nabidae. Fauna of the USSR. Nauka, Leningrad, 326 pp. [in Russian].

Koschel H. 1971: Zur Kenntnis der Raubwanze Himacerus apterus F. (Heteroptera, Nabidae). Teil 1. Z. Angew. Entomol. 68: $1-24$.

Kott P., Roth S. \& Reinhardt K. 2000: Hibernation mortality and sperm survival during dormancy in female Nabidae (Heteroptera: Nabidae). Opusc. Zool. Flumin. 182: 1-6.

Latrin J.D. 1989: Bionomics of the Nabidae. Annu. Rev. Entomol. 34: 383-400.

Maklakov A.A., Fricke C. \& Arnqvist G. 2007: Sexual selection affects lifespan and ageing in a beetle. Aging Cell 6: 739-744.

MeinKe L.J. \& Slosser J.E. 1985: Bracon mellitor Say (Hymenoptera: Braconidae) diapause in the Texas Rolling Plains. Ann. Entomol. Soc. Am. 78: 376-380.

Musolin D.L. \& SAulich A.H. 1999: Diversity of seasonal adaptations in terrestrial true bugs (Heteroptera) from the temperate zone. Entomol. Sci. 2: 623-639.

Norry F.M., Sambucetti P., Scannapieco A.C. \& Loeschcke V. 2006: Altitudinal patterns for longevity, fecundity and senescence in Drosophila buzzatii. Genetica 128: 81-93.

Nylin S. \& GotthardT K. 1998: Plasticity in life-history traits. Annu. Rev. Entomol. 43: 63-83.

Peel M.C., Finlayson B.L. \& McMahom T.A. 2007: Updated world map of the Köppen-Geiger climate classification. Hydrol. Earth Syst. Sci. 11: 1633-1644.

Pener M.P. 1992: Environmental cues, endocrine factors, and reproductive diapause in male insects. Chronobiol. Intern. 9: $102-113$.

PÉRICART J. 1987: Hemiptères Nabidae d'Europe occidentale et du Maghreb. Fauna de France 71: 1-181.

Remane R. 1964: Weitere Beiträge zur Kenntnis der Gattung Nabis Latr. (Hemiptera, Heteroptera, Nabidae). Zool. Beitr. 10: $253-314$.

Remane R. \& Thielen U. 1978: Steuerungsmechanismen beim Kopulationsverhalten von Nabiden-Arten (Hemiptera - Heteroptera) - ein Beitrag zur Frage der Beziehung zwischen Organstruktur, Funktion und Evolution. Z. Wiss. Zool. 186: 89-197.

Robinson S.J.W., ZwaAn B. \& Patridge L. 2000: Starvation resistance and adult body composition in a latitudinal cline of Drosophila melanogaster. Evolution 54: 1819-1824.
Roth S. \& Remane R. 2003: Zur Reproduktionsbiologie der Nabinae (Insecta: Heteroptera: Nabidae). Entomol. Abh. Staatl. Mus. Tierk. Dresden 60: 3-22.

Roth S. \& Reinhardt K. 2003: Facultative sperm storage in response to nutritional status in a female insect. Proc. R. Soc. Lond. (B) (Suppl.) 270: S54-S56.

Roth S., Janssen A. \& SAbelis M.W. 2008: Odour-mediated sexual attraction in nabids (Heteroptera: Nabidae). Eur $J$. Entomol. 105: 159-162.

Ruberson J.R., King T.J. \& ElKassabany N. 1998: Overwintering and the diapause syndrome of predatory Heteroptera. In Coll M. \& Ruberson J.R. (eds): Predatory Heteroptera: Their Ecology and Use in Biological Control. Entomological Society of America, Lanham, MD, pp. 89-130.

Ruberson J.R., Yeargan K.V. \& Netwon B.L. 2001: Variation in diapause responses between geographic population of the predator Geocoris punctipes (Heteroptera: Geocoridae). Ann. Entomol. Soc. Am. 94: 116-122.

Selander B.B. \& WeddLe R. 1972: The ontogeny of blister beetles (Coleoptera, Meloidae) III. Diapause termination in coarctate larvae of Epicauta segmenta. Ann. Entomol. Soc. Am. 65: 1-17.

Sharmila Bharathi N., Prasad N.G., MallikarJun ShaKarad \& AмitabH Joshi 2003: Variation in adult life history and stress resistance across five species of Drosophila. J. Genet. 82: 191-205.

Shimizu T. \& KaWASAKI K. 2001: Geographic variability in diapause response of Japanese Orius species. Entomol. Exp. Appl. 98: 303-316.

Sims S.R. \& ShaPIRo A.M. 1983: Pupal diapause in Battus philenor (Lepidoptera: Papilionidae). Ann. Entomol. Soc. Am. 76: 407-412.

Sørensen J.G., Norry F.M., Scannapieco A.C. \& Loeschcke V. 2005: Altitudinal variation for stress resistance traits and thermal adaptation in adult Drosophila buzzatii from the New World. J. Evol. Biol. 18: 829-837.

Tachibana S.-I. \& Watanabe T. 2007: Sexual differences in the crucial environmental factors for the timing of postdiapause development in the rice bug Leptocorisa chinensis. $J$. Insect Physiol. 53: 1000-1007.

Tatar M., Chien S.A. \& Kiefer Priest N. 2001: Negligible senescence during reproductive diapause in Drosophila melanogaster. Am. Nat. 158: 248-258.

Tauber M.J., Tauber C.A. \& Masaki S. 1986: Seasonal Adaptations of Insects. Oxford Univ. Press, Oxford, $411 \mathrm{pp}$.

TAYLOR F. \& KARBAN R. (eds) 1984: The Evolution of Insect Life Cycles. Springer, New York, $287 \mathrm{pp}$.

Wittenberg R. \& Cramer H. 1992: Datenanalyse mit SPSS. Gustav Fischer, Stuttgart, 734 pp.

Received August 12, 2008; revised and accepted October 22, 2008 